\title{
Variations in water level and glacier mass balance in Nam Co lake, Nyainqentanglha range, Tibetan Plateau, based on ICESat data for 2003-09
}

\author{
Hongbo WU, ${ }^{1,2}$ Ninglian WANG, ${ }^{1,3}$ Xi JIANG, ${ }^{4}$ Zhongming GUO ${ }^{1,2}$ \\ ${ }^{1}$ Cold and Arid Regions Environmental and Engineering Research Institute, Chinese Academy of Sciences, Lanzhou, China \\ E-mail: nlwang@Izb.ac.cn \\ ${ }^{2}$ University of Chinese Academy of Sciences, Beijing, China \\ ${ }^{3}$ State Key Laboratory of Cryospheric Sciences, Lanzhou, China \\ ${ }^{4}$ School of Atmospheric Science, Nanjing University of Information Science and Technology, Nanjing, China
}

\begin{abstract}
Water level fluctuations of inland lakes are related to regional-scale climate changes, and reflect variations in evaporation, precipitation and glacier meltwater flowing into the lake area in its catchment. In this paper, Ice, Cloud and land Elevation Satellite (ICESat) altimeter data and Landsat imagery (2002-09) are used to estimate Nam Co lake (Nyainqentanglha range, Tibetan Plateau) water elevation changes during 2002-09. In $2003 \mathrm{Nam}$ Co lake covered an area of $\sim 1998.8 \pm 4.2 \mathrm{~km}^{2}$ and was situated at $4723 \mathrm{~m}$ a.s.I. Over such inland water bodies, ICESat altimeter data offer both wide coverage and spatial and temporal accuracy. We combine remote-sensing and GIS technology to map and reconstruct lake area and increased volume changes during a 7 year time series. Nam Co lake water level increased by $2.4 \pm 0.12 \mathrm{~m}\left(0.33 \mathrm{~m} \mathrm{a}^{-1}\right)$ between 23 February 2003 and 1 October 2009 , and lake volume increased by $4.9 \pm 0.5 \mathrm{~km}^{3}$. In the past 7 years, Nam Co lake area has increased from $1998.78 \pm 5.4$ to $2023.8 \pm 3.4 \mathrm{~km}^{2}$, the glacier-covered area has decreased from 832.34 to $821.0 \mathrm{~km}^{2}$ and the drainage basin area has decreased from $201.1 \pm 4.2$ to $196.1 \pm 2.3 \mathrm{~km}^{2}$. However, the most spectacular feature is the continual water level rise from 2003 to 2009 without an obvious associated increase in precipitation. Based on digital elevation models (DEMs) from Shuttle Radar Topography Mission (SRTM) DEM data and corrected ICESat elevation data, significant changes to glacier mass balance in the western Nyainqentanglha mountains are indicated. Nyainqentanglha mountain glacier surface elevations decreased by $8.39 \pm 0.45 \mathrm{~m}$ during 2003-09. Over the same period, at least $1.01 \mathrm{~km}^{3}$ of glacial meltwater flowed into Nam Co lake, assuming a glacial runoff coefficient of 0.6. The mean glacier mass-balance value is $\mathbf{- 4 9 0} \mathrm{mm}$ w.e. over the corresponding period, indicating that glacier meltwater in the catchment contributes to lake level rise. The contribution rate of glacial meltwater to lake water volume rise is $\mathbf{2 0 . 7 5 \%}$. The temporal lake level fluctuation correlates with temperature variations over the same time span.
\end{abstract}

KEYWORDS: climate change, glacier fluctuations, glacier mass balance, remote sensing

\section{INTRODUCTION}

Glacier meltwater in the Tibetan Plateau (TP) is considered an important contributor to global sea-level rise (Meier and others, 2007), but the glaciers and surrounding lakes play an important role in the discharge of headwaters of many Asian rivers (Immerzeel and Bierkens, 2012), which are sensitive to global change. The TP boasts the greatest concentration of high-altitude inland lakes in the world (Zhang and others, 2011a), and these lakes are the subject of complex efforts to quantify how their mass balance changes. Lakes on the central TP have expanded significantly in recent decades, and the causes of the lake growth are still not well understood (Phan and others, 2012). Because inland lakes often contain glaciers in their catchment, their stability is closely associated with surrounding glacier and permafrost change, with glacial meltwater increase contributing significantly to inland lake level rise. Global water-mass variations are estimated using lidar and gravitational satellite measurements of Earth's gravitational field (Moiwo and others, 2011). Ice, Cloud and land Elevation Satellite (ICESat) altimeter data are a valid source of information on surface elevation change and the mass balance of mountain glaciers
(Kropáček and others, 2013). The glacier mass balance was validated by comparison with another geodetic approach based on the subtraction of two digital elevation models (DEMs) from 2000 and 2009. In the Hindu KushKarakoram-Himalaya region, a paucity of appropriate glacier data has prevented a comprehensive assessment of current regional mass balance (Kääb and others, 2012).

In addition, data from spaceborne altimeter missions, such as Topex/Poseidon, the Geosat Follow-On (GFO) satellite, European Remote-sensing Satellite-2 (ERS-2), Jason-1, Jason2, Envisat and ICESat, have been available since 1993 (Crétaux and others, 2011). It is possible to infer the mass balance from some proxy estimated using a number of remote-sensing approaches. The Geoscience Laser Altimeter System (GLAS) instrument carried on ICESat has provided a new, precise and global view of the vertical dimension of the Earth's surface and atmosphere. The accuracy of GLAS data is a few centimeters over flat surfaces (Herzfeld and others, 2008) but is much lower over rough terrain (Abshire and others, 2005). Lake level data, which constitute one of the most important and fundamental datasets used in hydrologic analysis, are obtained through gauge measurements and 


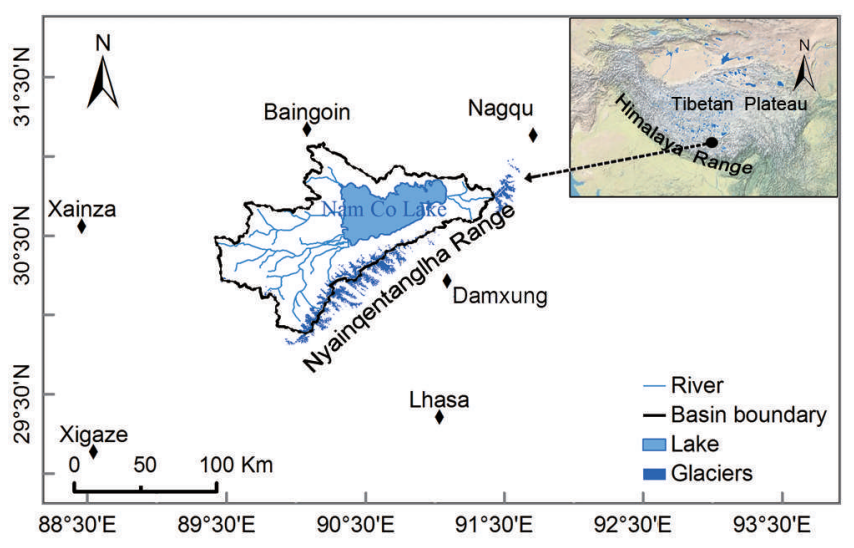

Fig. 1. The location of Nam Co lake basin and glaciers covered in the western Nyainqentanglha range, Tibetan Plateau. The altitudes of Baingoin, Xianza, Damxung, Lhasa, Xigaze and Nagqu meteorological stations are 4700, 4672, 4200, 3648, 3836 and 4507 ma.s.l., respectively. The distance from Nam Co basin to these stations ranges from 30 to $150 \mathrm{~km}$.

ICESat altimeter data (Zhang and others, 2011b). The ICESat GLAS data reveal that 30 of the lakes in the TP show a significant upward trend $\left(0.2-0.6 \mathrm{~m} \mathrm{a}^{-1}\right)$ in water level during 2003-09, particularly those inland lakes that are supplied with a large proportion of glacial meltwater (Song and others, 2013). Accurate quantification of the lake water input and output for Nam Co lake is hindered by the limited number of ground measurements (Kropáček and others, 2012).

Given the heterogeneity of water level stations, remotesensing imagery and laser altimeter data are useful complementary techniques for monitoring lake water level variations. Airborne and spaceborne remote sensing is the most practical approach for deriving a wide-area, regional assessment of lake level and glacier mass-balance change. In addition to spatial or temporal coverage and sampling rates, one of the most relevant criteria for inland water level change based on satellite altimetry data is the accuracy of the elevation data. The proportion of glacier meltwater in August every year was estimated to be $\sim 56 \%$ at Bow River, Banff, Alberta, Canada (Hopkinson and Young, 1998). The accuracy of ICESat altimeter data was assessed in a study of water level variation in the Great Lakes, North America, and an overall bias of $\sim 4.6 \mathrm{~cm}$ (underestimation) was computed (Abdallah and others, 2011). Mass-balance observations on Ürümqi river glacier No. 1 and Tuyuksu glacier in the Tien Shan show a large deficit during the 1980s compared with previous decades. Qinghai lake water level variation in the northeastern TP is consistent with glacier mass balance, but the specific variation in the relevant period is not known (Shi, 1990). The trend in water level change in Nam Co lake varied increasingly (at a rate of $0.62 \mathrm{~m} \mathrm{a}^{-1}$ ) during 2003-09, probably due to snow or glacier meltwater under climatic warming (Wang and others, 2013).

However, these new observation technologies reveal unexpected complexities in the glacier mass-balance response to Nam Co lake water level. In this paper, we apply ICESat/GLAS footprint data and Landsat multispectral remote-sensing imagery to Nam Co lake and Nyainqentanglha range glacier mass-balance in situ data. The aim is to find excellent basin-scale agreement of their temporal mass variations and trends, based on remote-sensing, GIS and mass-balance analysis. Finally, we discuss how climatic changes and glacier mass loss influence the inland lake water level on the central TP, and how the dataset could be exploited more fully.

\section{STUDY AREA}

Nam Co lake (the highest lake in the TP) is located in the west of the Nyainqentanglha mountains $\left(29^{\circ} 56^{\prime}-31^{\circ} 7^{\prime} \mathrm{N}\right.$, $89^{\circ} 21-91^{\circ} 23^{\prime} \mathrm{E}$ ), with an elevation of $4723 \mathrm{~m}$ a.s.l. and an area of $1998.78 \mathrm{~km}^{2}$ (in 2003). Figure 1 shows the location of glaciers and Nam Co lake in the study area. Nam Co basin is a closed catchment with an area of $\sim 10970 \mathrm{~km}^{2}$. The average elevation of the western Nyainqentanglha mountains is $\sim 5500 \mathrm{~m}$ a.s.l., and there were 1020 glaciers on the mountains in the 1970s. About $90 \%$ of the glaciers are situated on a $0-40^{\circ}$ slope. The elevation of the glacier-covered area ranges from 4870 to $7162 \mathrm{~m}$ a.s.I. and the total area was $832.34 \pm 30 \mathrm{~km}^{2}$ in 2002 . Meltwater from 267 glaciers flows into Nam Co lake, and the glacier area in the catchment was $201 \pm 11 \mathrm{~km}^{2}$ in 2002 . The annual precipitation is focused on May-September (Zhou and others, 2010) and is dominated by westerlies. The glacier area is at the margin of the dominant Indian monsoon, with an average annual precipitation of $414 \mathrm{~mm}$ at Nam Co station $\left(30^{\circ} 46.44^{\prime} \mathrm{N}, 90^{\circ} 59.31^{\prime} \mathrm{E}\right.$; $4730 \mathrm{~m}$ a.s.l). The catchment is little affected by human activities, so the lake and glaciers evolve mainly by adapting to natural conditions and climate change.

\section{DATASET \\ ICESat GLAS data acquisition}

ICESat is a scientific satellite launched by NASA on 13 January 2003 with the primary objective of measuring changes in ice-sheet elevation and sea-ice freeboard (Schutz and others, $2005)$. The accuracy of GLAS altimeter data is $\sim 2-14 \mathrm{~cm}$ (Zwally and others, 2002). GLAS laser footprints on the ground are $\sim 70 \mathrm{~m}$ in diameter at $\sim 170 \mathrm{~m}$ intervals (sampling at $40 \mathrm{~Hz}$ ) along the sub-satellite track. ICESat/GLAS orbited three times per year during 2003-09, and 18 campaigns ( $~ 33$ days per campaign) of data have been obtained. ICESat/GLAS offers 15 products (GLA01, GLA02, ..., GLA15 data), which can be downloaded from the US National Snow and Ice Data Center (NSIDC) website (http:// nsidc.org/data/icesat). In this study, the GLA01 product (1064 nm) was used to record the full waveform data, and GLA14 (Elevation Data Product) was applied to visualize the location of the corresponding ICESat/GLAS footprints. The GLA01 and GLA14 products were acquired from 23 February 2003 to 1 October 2009 (release Nos. 31 and 33), and 6095 waveforms of elevation data (4480 shots in glaciers) are used in this study (Table 1). The GLA14 elevation data, referenced to the World Geodetic System 1984 ellipsoidal elevation (WGS84) coordinate system, are computed using the centroid of the received pulse, as well as the centroid of the transmitted pulse. The pulse peak location of Gaussian fitted to the waveform is used to determine the centroid of the surface return and its range (Yi and others, 2003). However, ICESat elevation data are corrected by Gaussian and centroid elevation correction (G-C) for each of the ICESat laser campaigns; these G-C correction files are provided by the NSIDC (http://nsidc.org/data/icesat/correction-to-productsurface-elevation.html). In Figure 2, the green circles depict the GLAS footprint distribution in the glacier and lake areas. 


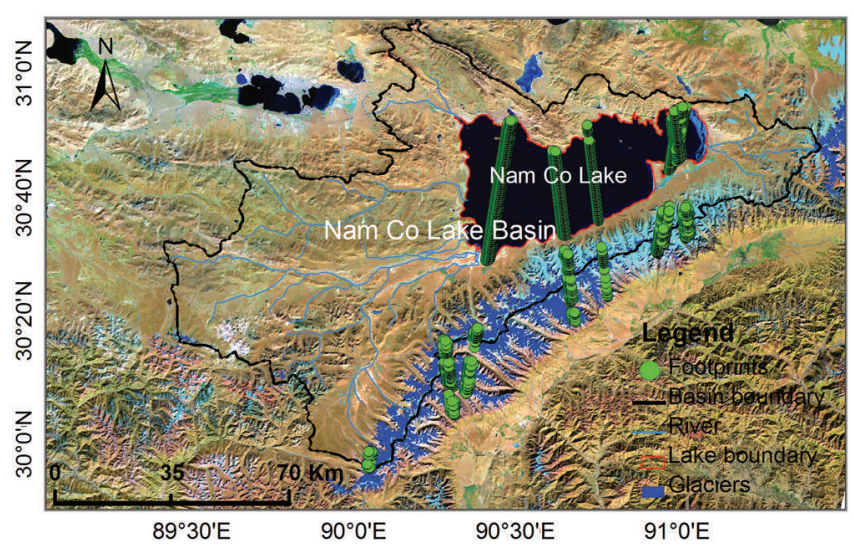

Fig. 2. Map of Nam Co lake catchment in the western Nyainqentanglha mountains on the northern slopes of the Himalaya. Distribution of ICESat GLAS footprints in the lake and glaciers is shown. The green circles are footprints available from GLA14 data from 2003 to 2009. Color composite images are synthesized with the TM7, TM4 and TM2 bands of the Landsat ETM image of 15 May 2002.

\section{Multispectral image and DEM}

For cloud cover $<25 \%$, 46 scenes of remote-sensing data are available, including Landsat Thematic Mapper/Enhanced Thematic Mapper (TM/ETM) data from the period 2002-09, which are navigated by the United States Geological Survey (USGS) GloVis website (http://glovis.usgs.gov/; Table 2). After multispectral image correction and orthorectification, the lake or glacier boundary is extracted by the supervised classification method, and its accuracy is assessed with observation data. As for the lake boundary and area variations, we used a Landsat ETM image of 15 May 2002 as a reference, and the following 45 scenes to make the lake area or increased water volume changes on the basis of 2002. Nam Co lake and the surrounding glaciers are mostly covered by one scene, the path/row of which is 138/39 in the Worldwide Reference System-2.

The Shuttle Radar Topography Mission (SRTM) DEM was obtained in February 2000 and acquired C-band $(5.6 \mathrm{~cm})$ synthetic aperture radar (SAR) images of the Earth's surface at $60^{\circ} \mathrm{N}, 56^{\circ} \mathrm{S}$, which can be downloaded from the USGS website. Both ICESat elevation and SRTM DEM data can be used to identify abnormal areas, such as cloud cover, cliffs, ridges and dams. The pixel resolution is $\sim 90 \mathrm{~m}$, and the 1 standard deviation error of the SRTM DEM over Nam Co lake basin is $6.4 \mathrm{~m}$ in terms of the absolute geo-reference, absolute height and relative height (Hirt and others, 2010). The SRTM DEM can be derived from the slope and elevation data in order to correct the ICESat altimeter data.

\section{Meteorological data}

Meteorological observation data from Baingoin, Xianza, Damxung, Lhasa, Xigaze and Nagqu meteorological stations were used to analyze climate change in the region (Fig. 1). We obtained air temperature and precipitation data from 2003 to 2009, and calculated the evaporation (Zhang and others, 2007). The observation meteorological data sources are the China Meteorological Administration's modeling precipitation $P$ and evaporation $E_{P}$. Precipitation in the middle zone of the Nam Co basin was then calculated by interpolating between the six stations using an inverse distance weighted (IDW) method in ArcGIS software (Fig. 2).
Table 1. Details of the ICESat altimeter data available for this study. Date format is yyyy-mm-dd

\begin{tabular}{|c|c|c|c|c|c|}
\hline Start date & End date & $\begin{array}{c}\text { Laser } \\
\text { sensor } \\
\text { identity }\end{array}$ & $\begin{array}{c}\text { Release } \\
\text { No. }\end{array}$ & $\begin{array}{c}\text { Footprint } \\
\text { No. in } \\
\text { lake area }\end{array}$ & $\begin{array}{c}\text { Footprint } \\
\text { No. in } \\
\text { glacier area }\end{array}$ \\
\hline $2003-02-23$ & 2003-03-27 & $\mathrm{L} 2 \mathrm{~A}$ & 31 & 724 & 127 \\
\hline 2003-09-27 & 2003-11-07 & L2B & 31 & 415 & 95 \\
\hline 2004-02-25 & 2004-03-10 & L2B & 31 & 188 & 62 \\
\hline 2004-05-26 & 2004-06-09 & L2C & 31 & 86 & 40 \\
\hline 2004-10-12 & 2004-11-06 & L3A & 33 & 346 & 106 \\
\hline $2005-02-27$ & 2005-03-12 & L3B & 33 & 138 & 58 \\
\hline 2005-05-29 & 2005-06-11 & L3C & 33 & 141 & 61 \\
\hline 2005-10-30 & 2005-11-12 & L3D & 33 & 177 & 87 \\
\hline 2006-03-02 & 2006-03-27 & L3E & 31 & 332 & 112 \\
\hline 2006-06-01 & 2006-06-15 & L3F & 31 & 160 & 74 \\
\hline 2006-11-02 & 2006-11-27 & L3G & 31 & 387 & 161 \\
\hline 2007-03-20 & 2007-04-14 & $\mathrm{L} 3 \mathrm{H}$ & 31 & 402 & 178 \\
\hline 2007-10-11 & 2007-10-24 & L3I & 31 & 176 & 86 \\
\hline 2008-02-25 & 2008-03-21 & L3J & 31 & 66 & 36 \\
\hline 2008-10-12 & 2008-10-12 & L3K & 31 & 320 & 142 \\
\hline 2008-12-06 & 2008-12-17 & L2D & 31 & 274 & 133 \\
\hline 2009-03-17 & 2009-03-22 & $\mathrm{L} 2 \mathrm{E}$ & 31 & 94 & 34 \\
\hline 2009-09-30 & 2009-10-01 & $\mathrm{L} 2 \mathrm{~F}$ & 31 & 54 & 23 \\
\hline
\end{tabular}

As there were significant differences in the observed precipitation at the six meteorological stations, Nam Co basin was assumed to be uniform with a value of $615 \mathrm{~mm}$. The amount of precipitation falling at the lake was found to be $\sim 600 \mathrm{~mm}$ (Zhou and others, 2013).

Figure 3 shows the summer precipitation and summer temperature variations for Nam Co lake basin, interpolated by the IDW method at the six observation stations, during the period 1 May-30 September 2003-09 (referred to as the summer period). There are larger differences in monthly precipitation among the stations in the Nam Co basin, but precipitation at each station ranges from 300 to $600 \mathrm{~mm}$. When considering an expanded region including six stations, the summer average temperature displays an increasing trend during 2003-09, except for 2008.

Table 2. Details of remote-sensing dataset used to estimate the Nam Co lake area during 2002-09. Date format is yyyy-mm-dd

\begin{tabular}{|c|c|c|c|}
\hline $\begin{array}{l}\text { Satellite } \\
\text { platform }\end{array}$ & Sensor & Date & $\begin{array}{l}\text { Spatial } \\
\text { resolution }\end{array}$ \\
\hline
\end{tabular}

$\mathrm{m}$

Landsat 5 TM 2003-12-20; 2004-10-19; 2005-09-20; 28.5 2005-11-07; 2006-05-18; 2006-08-06; 2006-10-09; 2007-01-29; 2007-05-05; 2007-07-08; 2008-01-16; 2008-06-08; 2008-11-15; 2009-01-18; 2009-08-30; 2009-11-02

Landsat $7 \quad$ ETM 2002-05-15; 2003-01-10; 2003-04-16; 2003-11-10; 2003-11-18; 2003-11-26; 2003-12-12; 2004-03-17; 2004-05-12; 2004-10-11; 2004-12-14; 2005-10-14; 2005-11-15; 2005-12-17; 2006-01-02; 2006-01-18; 2006-12-04; 2007-05-29; 2007-08-01; 2007-09-18; 2007-11-21; 2007-12-23; 2008-01-08; 2008-02-09; 2008-11-23; 2008-12-09; 2009-04-16; 2009-05-02; 2009-10-25; 2009-11-10 


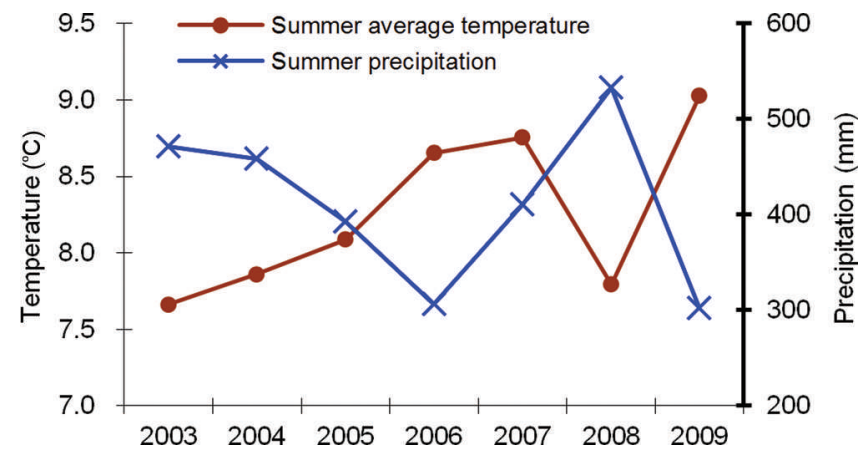

Fig. 3. Summer precipitation and average summer temperature variations in Nam Co basin. The brown line indicates average temperature and the blue line is summer precipitation from 1 May to 30 September 2003-09.

\section{METHODS}

\section{Lake area estimation}

The TM/ETM images provide information about changes in maximum lake area extent. Lake boundaries were extracted by the supervised classification method based on true color synthesizing images in ERDAS 9.1 software. All the vector format boundary and image data were projected into the Universal Transverse Mercator (UTM) coordinate system Zone 45 under the WGS84 datum. The modified normalized-difference water index (MNDWI) was used to map the lake water bodies (McFeeters, 1996). The area of Nam Co lake on 16 April 2009 was $2022.7 \pm 10.7 \mathrm{~km}^{2}$, which is consistent with the lake area finding (Zhang and others, 2013) on the same date.

We then establish the statistical relationship between the lake surface area and the water level, to reconstruct a lake water area time-varying series from Landsat images of 200309 (Krause and others, 2010). Next we estimate lake water increased storage variations and the changes therein, combined lake area and water level time-varying series data estimated by the TM/ETM images and the GLAS/ICESat L2 Global Land Surface Altimetry Data (GLA14). The River and Lake Project of the European Space Agency (ESA) and De Montfort University, Leicester, UK, is based on altimeter data (i.e. ERS-2, Envisat and Jason-2) to provide lake, reservoir and river water level observation data. The dataset, available at the ESA/De Montfort University River and Lake website (http://tethys.eaprs.cse.dmu.ac.uk/RiverLake/shared/ main), validated the Nam Co lake water level and area variations. As shown in Figure 4, the lake surface elevation record shows apparent spatial differences in observation data and GLAS footprint data, reflecting the varying character of climate change on the central TP. Full details of product generation procedures are provided in the River and Lake Product Handbook v3.5 (2009).

\section{Lake water increased volume variation}

All GLAS footprints in the latitude direction on different campaigns could be satisfied with the lake water level monitoring. Taking the locations of both maximum and minimum as ends, we can calculate the GLAS footprint elevation average value as lake level at that time. Because detailed bathymetric maps are lacking, we estimated the variation of lake water storage increased volume based on lake water level rise and lake area expansion (Lei and others,
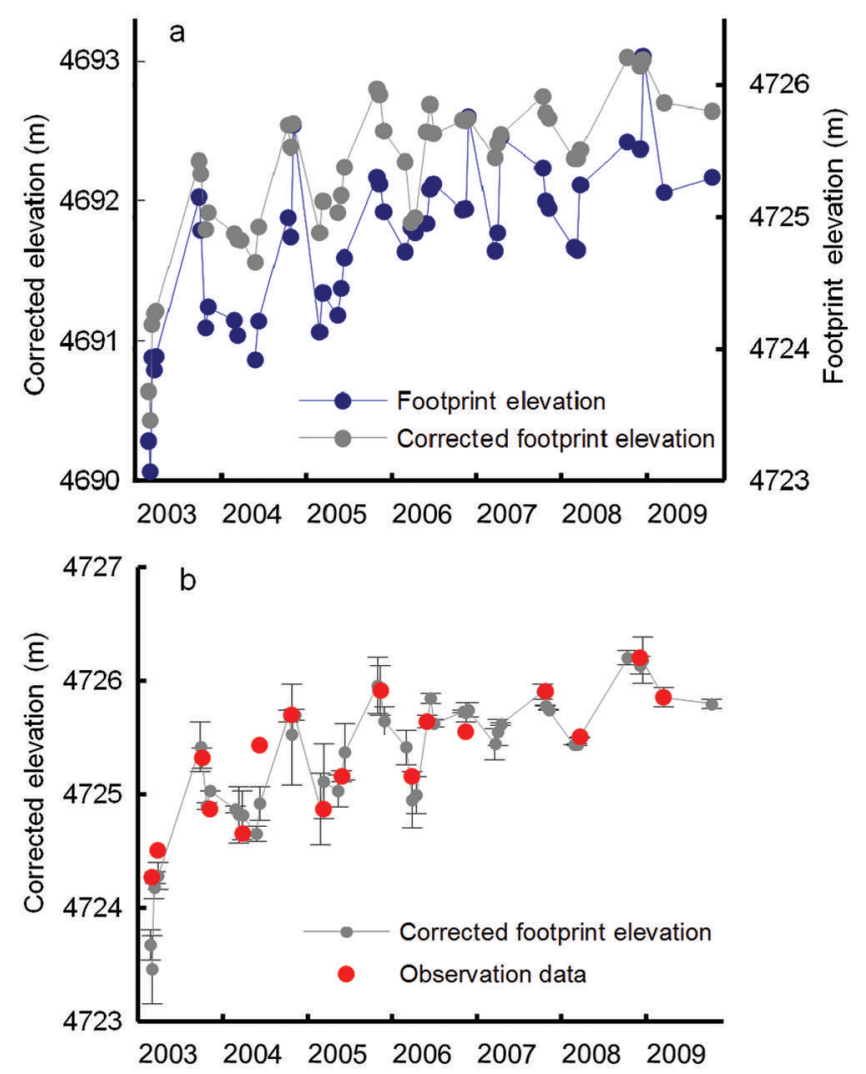

Fig. 4. (a) Comparison of lake water surface elevation based on GLA14 product, and corrected GLAS footprint elevation estimated by geoid height (in the geoid EGM2008 model) in Nam Co lake basin from February 2003 to October 2009. (b) The difference in corrected GLAS footprint elevation and in situ observation data (red points). Error bars denote standard deviations of GLAS corrected footprint elevation along the ascending or descending track.

2013). Lake increased volume variation is

$$
V=\frac{1}{3} \times\left(S_{1}+\sqrt{S_{1} \times S_{2}}+S_{2}\right) \times h
$$

where $\Delta V$ is lake water increased volume $\left(\mathrm{km}^{3}\right)$, the variables $S_{1}$ and $S_{2}$ are lake area at two stages $\left(\mathrm{km}^{2}\right)$, and $\Delta h$ is the absolute change in water level height $(\mathrm{m})$ estimated by ICESat altimeter data between the two campaigns. The total lake water volume $\left(V_{t}\right)$ depends on a previous storage capability of Nam Co lake or reservoir $\left(V_{\text {con }}\right)$ and lake water increased volume $(\Delta V)$ owing to the water level rise, so the lake total volume can be expressed as (Duan and Bastiaanssen, 2013)

$$
V_{\mathrm{t}}=V_{\mathrm{con}}+\Delta V
$$

Considering the glacier meltwater flowing into the lake, the water mass balance of a closed lake can be expressed as

$$
\Delta V=\left(P-E_{\mathrm{p}}\right) \times S_{\text {lake }}+\left(S_{\mathrm{c}}-S_{\text {lake }}\right) \times R+G+M_{\mathrm{g}}
$$

where $\Delta V$ is the increased lake storage volume $\left(\mathrm{km}^{3}\right), P$ and $E_{\mathrm{P}}$ are annual precipitation $(\mathrm{mm})$ and annual evaporation $(\mathrm{mm})$ on the surface, respectively, $S_{\text {lake }}$ and $S_{\mathrm{c}}$ are lake water area and lake catchment area $\left(\mathrm{km}^{2}\right)$, respectively, $R$ is the runoff depth $(\mathrm{mm})$ in the theoretical model (i.e. the difference between precipitation and evapotranspiration on the land surface) and $G$ is groundwater input or output, including deep groundwater, hot springs and groundwater exchange among other basins. The surface groundwater inflow produced by atmospheric precipitation is also 
included in the equation, because $R$ is calculated through precipitation minus land evapotranspiration. The deep groundwater exchange is discounted as having a negligible impact on lake water mass balance. The variable $M_{\mathrm{g}}=0.6$ is the glacial runoff coefficient generated by glacier meltwater in the catchment, which is closely related to glacier surface ablation height and mass loss.

\section{Glacier mass-balance estimation}

The Earth Gravitational Model 2008 (EGM2008) geoid data (Pavlis and others, 2012) are applied to interpret SRTM elevations (in $30 \mathrm{~m}$ resolution) and GLAS footprint elevation and locations. The gauges or in situ GPS instruments measured (Bamber and Rivera, 2007) were converted into the GLAS data referenced WGS84 datum and EGM2008 geoid system. For example, in GLA14, these data provide a high-accuracy $(10 \mathrm{~cm})$ dataset for comparison. As will be illustrated below, they can be combined with raster-based SRTM DEM data to produce elevation change $(\mathrm{d} h / \mathrm{d} t)$ estimation (Kern and others, 2003; Sauber and others, 2005). The variances from the least-squares regression as weights are used to estimate the $\mathrm{d} h / \mathrm{d} t$ value from the corrected GLAS laser footprint elevation. The elevation errors present the tangent relationship with the slope in the terrain (Nuth and Kääb, 2011), in case that slope value can be calculated by any standard ArcGIS software. The observed geometric rates are corrected for laser footprint elevation changes not related to ice mass changes, including firn compaction, vertical bedrock movement and ICESat laser inter-campaign elevation bias (Sørensen and others, 2011). The uncertainty of the GLAS laser mass balance is estimated by sampled cross-track elevation (Moholdt and others, 2010).

The ICESat-measured surface elevation $E_{\mathrm{ie}}$ is referenced to an Earth ellipsoid, although GLAS surface elevations have instrument corrections ( $\mathrm{Yi}$ and others, 2011). Thus, we define the elevation $h$ above the geoids as

$$
h=E_{\mathrm{ie}}+\Delta E_{\mathrm{ib}}+E_{\mathrm{sat}}-h_{\mathrm{g}}
$$

where $E_{\text {sat }}$ is the corrected GLAS footprint elevation and $h_{\mathrm{g}}$ is the reference geoid height in the gravitational geoid model (EGM2008). Note that the influence of $\Delta E_{\mathrm{ib}}, E_{\mathrm{sat}}$ and $h_{\mathrm{g}}$ is removed from $E_{\mathrm{ie}}$, but there is still an effect from other factors (i.e. dynamic topography and the residuals; Berthier and others, 2007).

At each footprint, we calculate the elevation difference in two stages:

$$
\Delta h(x, y)=h_{\mathrm{i}}\left(x, y, t_{1}\right)-h_{\mathrm{i}}\left(x, y, t_{2}\right)=\frac{\mathrm{d} h}{\mathrm{~d} t} \times \Delta t
$$

where $t_{1}$ and $t_{2}$ are the times at which the ascending and descending track acquired data at the same spot. The time span $\Delta t=t_{1}-t_{2}$ ranges from $\sim 40$ to $\sim 140$ days.

The glacier ice, firn and snow density differ in the surface covered; the mass balance of glacier density $\rho_{\mathrm{i}}$ varies. If $\rho_{\mathrm{i}}$ is not a measured value, the density is estimated instead as an ice-snow average density. The glacier mass balance at an altitude interval of $200 \mathrm{~m}$ was calculated as

$$
b_{\mathrm{i}}=\left(\rho_{\mathrm{i}} \times \Delta h_{\mathrm{i}}\right) \times s_{\mathrm{i}}
$$

where $b_{\mathrm{i}}$ is the mass balance of each altitude interval zone, including glacier ice, snow and affiliated ice variation, so we define ice-snow average density as $\rho_{\mathrm{i}}=900 \mathrm{~kg} \mathrm{~m}^{-3}$, and $s_{\mathrm{i}}$ is the glacier projected area at a $200 \mathrm{~m}$ altitude interval under the WGS84 coordination reference system. The mass balance of the glaciers is calculated as

$$
b=\frac{1}{s} \sum_{\mathrm{i}=1}^{n} s_{\mathrm{i}} \times b_{\mathrm{i}}
$$

where the variable $s$ is the glacier area under the WGS84 coordinate reference system.

\section{Uncertain error and validation}

\section{Uncertain error}

The uncertainty errors of elevation data, whether highresolution DEM data or individual points, are commonly checked by fieldwork data or satellite ground-control points (GCPs). Combined photogrammetry and measured GCP data should ensure a reliable representation of the glacier surface (Keutterling and Thomas, 2006). An average vertical error $\varepsilon_{\mathrm{v}}$ is calculated as

$$
\varepsilon_{\mathrm{v}}= \pm(1+3 \tan \theta)
$$

where $\theta$ is the glacier surface slope value. At a topographic map scale of $1: 10000$, the GCP dataset is employed to georeference the aerial topographic map with a root-meansquare error (RMSE) of $3.5 \mathrm{~m}$. The same GCPs can ensure that all the multispectral satellite images match precisely.

With smaller glaciers, glacier terrain errors cannot be ignored, as they easily lead to glacier area and length uncertainty error (Kulkarni and others, 2007). Thus, the accuracy of the glacier boundary uncertainty error depends on the spatial resolution and geo-reference error in the remote-sensing imagery (Williams and others, 1997). The glacier or lake boundary uncertainty error (Nuth and Kääb, 2011) is calculated as

$$
I=\sqrt{\sum \lambda^{2}}+\sqrt{\sum \varepsilon^{2}}
$$

where $I$ is the uncertainty error value in the glacier or lake area, $\lambda$ is the original image spatial resolution or individual pixel size $(\mathrm{m})$ and $\varepsilon$ is the image of geo-reference errors in different periods. As the multiphase data error in glacier area uncertainty, Hall and others (2003) proposed

$$
a=\sum \lambda^{2} \times \frac{2 l}{\sqrt{\sum \lambda^{2}}}+\sum \varepsilon^{2}
$$

where $a$ is glacier area error, $\lambda$ is the spatial resolution of the remote-sensing images used $(\mathrm{m})$ and $\varepsilon$ is the geo-reference error images and should be controlled within $<5 \mathrm{~m}$. The glacier boundary uncertainty error for TM data is $\pm 21.2 \mathrm{~m}$ and the uncertainty error of the glacier area is $\pm 5.04 \mathrm{~km}^{2}$.

\section{Validation}

Validation of the ICESat altimeter-derived water level generally requires comparison with in situ measurements at gauging stations (Birkett and Beckley, 2010). The overflying tracks are usually some distance away from the ground gauging stations, but the ICESat altimeter dataderived water level rise is very significant. Yet it has to be noted that these GLAS footprints exhibit systematic intercampaign and inter-laser biases at two stages. Figure $4 a$ shows that the two curves form a good match for the lake water level of ICESat GLAS footprint-corrected data and the in situ measurements; both have a Pearson's correlation coefficient $r=0.91$. The standard deviation of GLAS-derived lake water elevation is $>0.11$, which might be attributed to floating ice or thin cloud backscattering. 

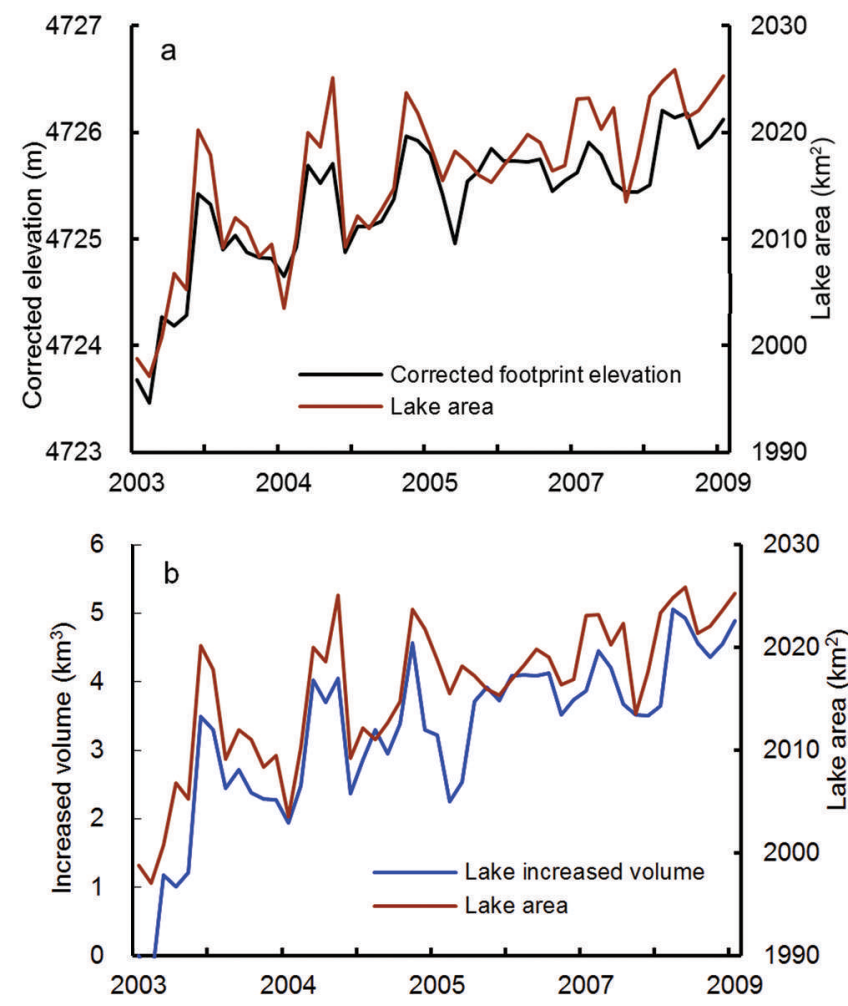

Fig. 5. The curves of lake water elevation derived from GLA14 product data, lake area and lake increased volume $\left(\mathrm{km}^{3}\right.$ w.e.) during 2003-09. (a) Lake area is estimated from the Landsat TM/ ETM dataset, and the lake water elevation is the corrected ICESat elevation derived from GLA14 product. (b) Nam Co lake increased volume calculated from lake area and water level change height (equivalent water height), from February 2003 to October 2009.

\section{RESULTS AND DISCUSSION}

\section{Lake area and volume changes}

The GLA14 product datasets provided useful information and curves of water level variations in Nam Co lake. The time-series curves show an obvious trend of water level rise and area expansion. Figure $5 \mathrm{a}$ presents the linear or quadratic models used to fit the water level rise and lake area data. There is significant correlation between lake water level elevation and lake water area, with a multiple correlation coefficient of $>0.85$. Linear regression of all measurements indicates the lake level increased by $2.4 \pm 0.12 \mathrm{~m}$ during 2003-09, which means an average annual rise of $0.33 \mathrm{~m}$ ( $t$ test value $=3.47, p<0.05$ ). Correspondingly, the water storage volume increased by $\sim 4.9 \pm$ $0.5 \mathrm{~km}^{3}$ (Fig. 5b), which is equivalent to the lake water level increasing at an average rate of $0.6978 \pm 0.11 \mathrm{~km}^{3} \mathrm{a}^{-1}$. As shown in Figure 5b, Nam Co lake area expanded dramatically from $1998.78 \pm 5.4$ to $2023.8 \pm 3.4 \mathrm{~km}^{2}$, at an average annual rate of $3.6 \mathrm{~km}^{2} \mathrm{a}^{-1}$, but has increased slowly since 2008.

In summary, in the absence of an associated obvious increase in precipitation, the recent trend in lake water level may be closely associated with increased summer temperature in the basin. Therefore, the inland lakes into which high-altitude mountain glacier meltwater flows are more likely to be influenced by climatic warming. Thus, the summer temperature rise results in glacier meltwater increase, and has also contributed to lake water level rise and an increase in water mass storage (Fig. 5b).
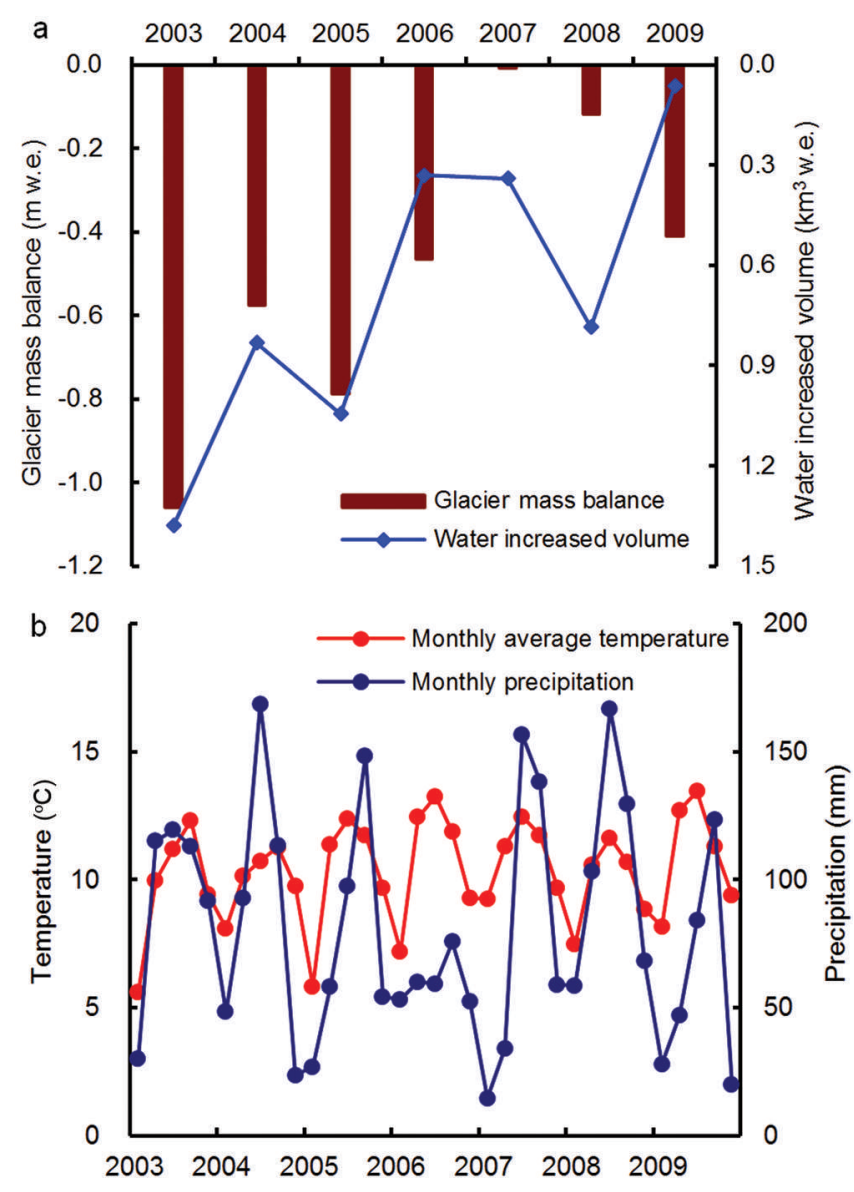

Fig. 6. (a) Comparison of water level and glacier mass-balance changes from 2003 to 2009. (b) The curves of average summer temperature and summer precipitation during 2003-09, interpolated from six observation stations by the IDW method.

\section{Glacier mass-balance change}

Figure 6 shows annual water level variations associated with glacier mass-balance trends from 2003 to 2009. It is impossible to identify their relationships in the Nam Co lake catchment. As shown in Figure 6a, the total glacier ice volume loss in the western Nyainqentanglha mountains is $1.69 \pm 0.12 \mathrm{~km}^{3}$ w.e. in the past 7 years at a rate of $0.2413 \pm 0.08 \mathrm{~km}^{3} \mathrm{a}^{-1}$. However, the average glacier mass loss for the past 7 years is $0.49 \mathrm{~m}$ w.e., and the trend in mass loss is slowing. In Figure 6a and b, glacier mass balance and summer temperatures have a positive correlation, indicating glacier sensitivity to summer air temperature, but there is no obvious correlation with summer precipitation. As summer temperature increases, there should be a large increase in glacial runoff. Whereas water level rose in 2007, it declined in 2008. In fact, in summer 2008, annual precipitation increased by $19.6 \%$, drainage basin runoff decreased by $33.3 \%$ and glacial meltwater decreased by $53.8 \%$. The reason for this is that solid precipitation (e.g. snow, sleet, hail), which is determined along with air temperature, is equivalent to accumulation on the glacier, and glacial meltwater should then decrease.

The quality of the DEM potentially could have been improved by additional smoothing and systematic bias corrections. This linearity is captured by the GLAS footprint data due to the fixed gaps along with the elevation. In order to estimate trends in surface elevation change, a linear regression was fitted with all GLAS footprint elevation 


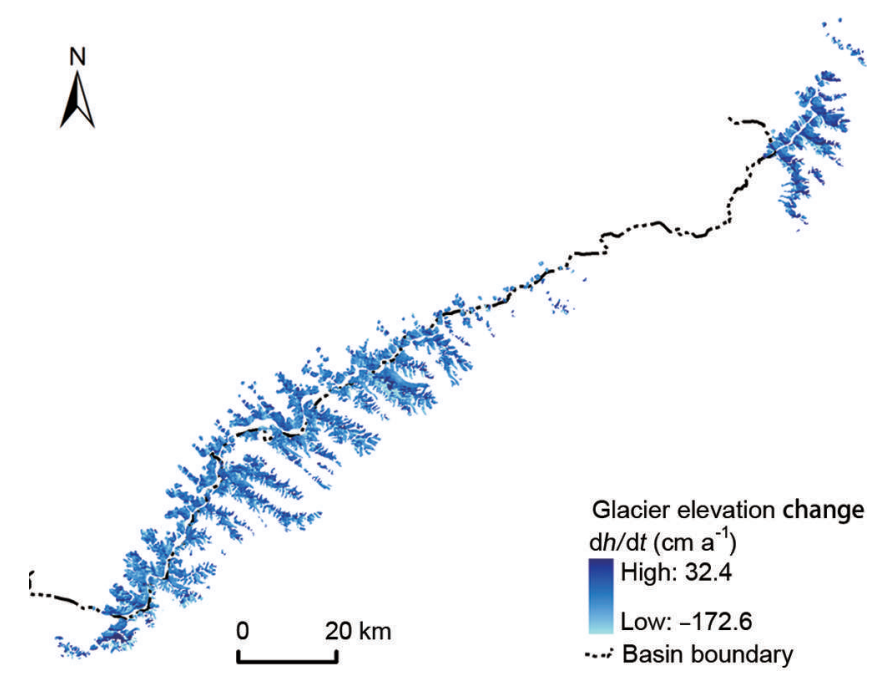

Fig. 7. Surface elevation changes $\left(\mathrm{d} h / \mathrm{d} t, \mathrm{~cm} \mathrm{a}^{-1}\right)$ from February 2003 to October 2009 for the glaciers in the western Nyainqentanglha mountains.

change $\Delta h$ values. The elevation changes $\mathrm{d} h / \mathrm{d} t\left(<2 \mathrm{~m} \mathrm{a}^{-1}\right)$ are the assumed GLAS footprint elevation change rates in Nyainqentanglha mountain glaciers (Fig. 7). In order to demonstrate trends in glacier change spatially, we applied a low-pass filter to reduce small-scale noise, but it did not improve the overall precision of the SRTM DEM data. In Figure 7 , the mass balance seems slightly more negative in the southern $\left(-0.53\right.$ to $\left.-0.92 \mathrm{mw}^{-e} \mathrm{a}^{-1}\right)$ than in the northern area $\left(-0.37\right.$ to $-0.65 \mathrm{~m}$ w.e. $\left.\mathrm{a}^{-1}\right)$, but these differences are insufficient to offset uncertainty error in the evaluation. Employing the GIS analytical method, the glacier surface region below $5800 \mathrm{~m}$ a.s.l. was estimated as $-1.03 \pm 0.4 \mathrm{~m} \mathrm{a}^{-1}$ during 2003-09. Similar differences were found for glaciers at the equilibrium-line altitude (ELA), which was 5800 ma.s.l. in 2009.

\section{Analysis of increased lake volume and glacier surface elevation change}

The results of Wu and Zhu (2008) show that during 19702000 the area of Nam Co lake increased from 1942.34 to $1979.79 \mathrm{~km}^{2}$ at a rate of $1.27 \mathrm{~km}^{2} \mathrm{a}^{-1}$, while glacier area decreased from 167.62 to $141.88 \mathrm{~km}^{2}$ at a rate of $0.86 \mathrm{~km}^{2} \mathrm{a}^{-1}$. In the basin, glaciers continued to shrink during 2002-09. No advancing glaciers were detected (Bolch and others, 2010). However, in the western Nyainqentanglha mountains, $\sim 960$ glaciers covering an area of $832.2 \pm 5.04 \mathrm{~km}^{2}$ shrank by $11.34 \mathrm{~km}^{2}$ during 2003-09 (at a rate of $1.61 \mathrm{~km}^{2} \mathrm{a}^{-1}$ ), with glaciers in the Nam Co lake catchment also decreasing, from $201.1 \pm 4.3$ to $196.1 \pm 2.3 \mathrm{~km}^{2}$ at a rate of $0.71 \mathrm{~km}^{2} \mathrm{a}^{-1}$, in this period.

Figure 6a shows lake water level rise or area expansion resulting from glacier meltwater inflow. Assuming a glacial runoff coefficient of 0.6 , the volume of inflow into the lake is $1.01 \mathrm{~km}^{3}$. The glacial meltwater inflow $(510 \mathrm{~mm}$ lake water depth) contributes at least $20.75 \%$ to lake water level rise. Thus, glacial meltwater indeed makes an important contribution to the positive water mass balance of Nam Co lake in the past 7 years, which is associated with the increase in summer temperature.

Figure 8 depicts the relationship between Nam Co lake water level and precipitation in interseasonal change, with May-September defined as the warm season and

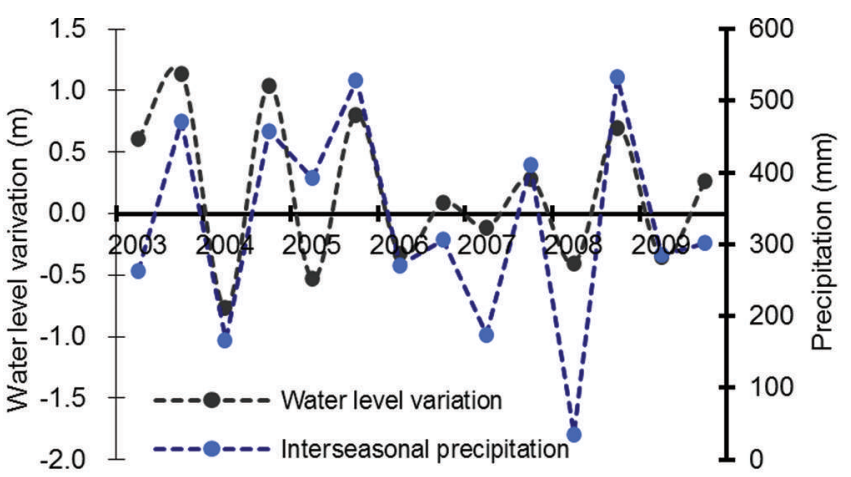

Fig. 8. Nam Co lake water level and precipitation interseasonal variation curves for 2003-09.

October-April in the next year as the cold season. Based on the glacier mass-balance results (Fig. 6a), annual precipitation during 2003-09 was estimated to contribute $50.75 \%$ of lake level rise. As there is a significant correlation between precipitation and lake water level on an interseasonal scale (Fig. 8), there is no clear evidence that the ratio of meltwater to the other mass-water input is known. However, continual lake water level rise is a direct response to summer temperature increase during 2003-09, and the slowing glacier mass loss indicates a sensitive response to this high-mountain precipitation increase.

\section{CONCLUSIONS}

Our results indicate that the Nam Co lake water level, area and annual increased volume variations during 2003-09 can be monitored using ICESat altimeter data and Landsat TM/ ETM imagery. Comparing lake level rise and glacier mass loss during this period, the contribution of glacier mass loss to Nam Co lake water level rise is relatively slight. It is consistent with a decrease in mountain glacier mass loss, indicating an increase in high-mountain regional precipitation. The following points have been addressed in this study:

1. During 2003-09, Nam Co lake water level increased continually, while mountain glaciers retreated. Nam Co lake water level rise and area expansion were dramatic, but have slowed. The lake area increased from $1998.78 \pm 5.4 \mathrm{~km}^{2}$ in 2002 to $2023.8 \pm 3.4 \mathrm{~km}^{2}$ in 2009, and the lake level increased by $2.4 \pm 0.12 \mathrm{~m}$ $\left(0.33 \mathrm{~m} \mathrm{a}^{-1}\right)$ over the same period. Accordingly, lake water volume growth is $4.9 \mathrm{~km}^{3}$, increasing at a rate of $0.6978 \mathrm{~km}^{3} \mathrm{a}^{-1}$.

2. In 2002, there were $\sim 960$ glaciers in the western Nyainqentanglha mountains, covering an area of $832.2 \pm 5.04 \mathrm{~km}^{2}$, and recession occurred at a rate of $1.61 \mathrm{~km}^{2} \mathrm{a}^{-1}$ during 2003-09. In the catchment, the glacier-covered area was $201.1 \pm 4.3 \mathrm{~km}^{2}$ in 2003, and decreased to $196.1 \pm 2.3 \mathrm{~km}^{2}$ in 2009 , at a rate of $0.71 \mathrm{~km}^{2} \mathrm{a}^{-1}$. We consider the summer temperature rise to be a major influence on glacier ice melt. With regard to glacier mass loss, the glacier meltwater is caused by rising air temperature. Precipitation appears to be related to the slowing of glacier mass loss during 2003-09.

3. Lake water level increase or area expansion is induced by glacier meltwater, and increased precipitation directly affects water runoff generation. Assuming a glacial runoff 
coefficient $M_{g}=0.6$, the glacial meltwater inflow volume is at least $1.01 \mathrm{~km}^{3}$ during 2003-09. The glacial meltwater inflow ( $\sim 510 \mathrm{~mm}$ water depth) contributes a lake water level rise of $20.75 \%$ over the corresponding time span. The results also show that information on transient water level elevation can be usefully applied to determine increased lake volume variations.

\section{ACKNOWLEDGEMENTS}

This work was supported by the National Key Basic Research Development Program of China (grant No. 2010CB951404), the Strategic Science and Technology Program of the Chinese Academy of Sciences (grant No. XDB03030204) and the National Natural Science Foundation Project of China (grant No. 40930526 and No. 41190084). We thank the Nam Co lake stations and the Laboratoire d'Etudes en Géophysique et Océanographie Spatiales for providing Nam Co lake water level monitoring and for validating the data and methods, Jianchen $\mathrm{Pu}$ for providing in situ glacier boundary and GCPs, and Yanqiu Xing for the processing methods of the ICESat altimeter data. We also thank the China Meteorological Data Sharing Service System of the China Meteorological Administration (CMA) for providing meteorological observation data for this study.

\section{REFERENCES}

Abdallah H, Bailly J-S, Baghdadi N and Lemarquand N (2011) Improving the assessment of ICESat water altimetry accuracy accounting for autocorrelation. ISPRS J. Photogramm. Rem. Sens., 66(6), 833-844 (doi: 10.1016/j.isprsjprs.2011.09.002)

Abshire JB and 7 others (2005) Geoscience Laser Altimeter System (GLAS) on the ICESat Mission: on-orbit measurement performance. Geophys. Res. Lett., 32(21), L21S02 (doi: 10.1029/ 2005GL024028)

Bamber JL and Rivera A (2007) A review of remote sensing methods for glacier mass balance determination. Global Planet. Change, 59(1-4), 138-148 (doi: 10.1016/j.gloplacha.2006.11.031)

Berthier E, Arnaud Y, Kumar R, Ahmad S, Wagnon P and Chevallier P (2007) Remote sensing estimates of glacier mass balances in the Himachal Pradesh (Western Himalaya, India). Remote Sens. Environ., 108(3), 327-338 (doi: 10.1016/j.rse.2006.11.017)

Birkett CM and Beckley B (2010) Investigating the performance of the Jason-2/OSTM radar altimeter over lakes and reservoirs. Mar. Geod., 33(Suppl. 1), 204-238 (doi: 10.1080/01490419.2010. 488983)

Bolch T and 7 others (2010) A glacier inventory for the western Nyainqentanglha Range and Nam Co Basin, Tibet, and glacier changes 1976-2009. Cryosphere, 4(2), 429-467 (doi: 10.5194/ tc-4-419-2010)

Crétaux J-F and 10 others (2011) SOLS: a lake database to monitor in the Near Real Time water level and storage variations from remote sensing data. Adv. Space Res., 47(9), 1497-1507 (doi: 10.1016/j.asr.2011.01.004)

Duan Z and Bastiaanssen WGM (2013) Estimating water volume variations in lakes and reservoirs from four operational satellite altimetry databases and satellite imagery data. Remote Sens. Environ., 134, 403-416 (doi: 10.1016/j.rse.2013.03.010)

Hall DK, Bayr KJ, Schöner W, Bindschadler RA and Chien JYL (2003) Consideration of the errors inherent in mapping historical glacier positions in Austria from ground and space (1893-2001). Remote Sens. Environ., 86(4), 566-577 (doi: 10.1016/S00344257(03)00134-2)

Herzfeld UC, McBride PJ, Zwally HJ and Dimarzio J (2008) Elevation changes in Pine Island Glacier, Walgreen Coast, Antarctica, based on GLAS (2003) and ERS-1 (1995) altimeter data analyses and glaciological implications. Int. J. Remote Sens., 29(19), 5533-5553 (doi: 10.1080/01431160802020510)

Hirt C, Filmer MS and Featherstone WE (2010) Comparison and validation of the recent freely available ASTER-GDEM ver1, SRTM ver4.1 and GEODATA DEM-9S ver3 digital elevation models over Australia. Austral. J. Earth Sci., 57(3), 337-347 (doi: 10.1080/08120091003677553)

Hopkinson C and Young GJ (1998) The effect of glacier wastage on the flow of the Bow River at Banff, Alberta, 1951-1993. Hydrol. Process., 12(10-11), 1745-1762 (doi: 10.1002/(SICl)10991085(199808/09)12:10/11<1745::AID-HYP692>3.0.CO;2-S)

Immerzeel WW and Bierkens MFP (2012) Asia's water balance. Nature Geosci., 5(12), 841-842 (doi: 10.1038/ngeo1643)

Kääb A, Berthier E, Nuth C, Gardelle J and Arnaud Y (2012) Contrasting patterns of early twenty-first-century glacier mass change in the Himalayas. Nature, 488(7412), 495-498 (doi: 10.1038/nature11324)

Kern M, Schwarz KKPP and Sneeuw N (2003) A study on the combination of satellite, airborne, and terrestrial gravity data. J. Geod., 77(3-4), 217-225 (doi: 10.1007/s00190-003-0313-x)

Keutterling A and Thomas A (2006) Monitoring glacier elevation and volume changes with digital photogrammetry and GIS at Gepatschferner glacier, Austria. Int. J. Remote Sens., 27(19), 4371-4380 (doi: 10.1080/01431160600851819)

Krause P, Biskop S, Helmschrot J, Flügel W-A, Kang S and Gao T (2010) Hydrological system analysis and modelling of the Nam Co basin in Tibet. Adv. Geosci., 27, 29-36 (doi: 10.5194/adgeo27-29-2010)

Kropáček J, Braun A, Kang S, Feng C, Ye Q and Hochschild V (2012) Analysis of lake level changes in Nam Co in central Tibet utilizing synergistic satellite altimetry and optical imagery. Int. J. Appl. Earth Obs. Geoinform., 17, 3-11 (doi: 10.1016/ j.jag.2011.10.001)

Kropáček J, Neckel N and Bauder A (2013) Estimation of volume changes of mountain glaciers from ICESat data: an example from the Aletsch glacier, Swiss Alps. Cryos. Discuss., 7(4), 3261-3291 (doi: 10.5194/tcd-7-3261-2013)

Kulkarni AV and 6 others (2007) Glacial retreat in Himalaya using Indian remote sensing satellite data. Current Sci., 92(1), 69-74

Lei Y, Yao T, Bird BW, Yang K, Zhai J and Sheng Y (2013) Coherent lake growth on the central Tibetan Plateau since the 1970s: characterization and attribution. J. Hydrol., 483, 61-67 (doi: 10.1016/j.jhydrol.2013.01.003)

McFeeters SK (1996) The use of the Normalized Difference Water Index (NDWI) in the delineation of open water features. Int. J. Remote Sens., 17(7), 1425-1432 (doi: 10.1080/ 01431169608948714)

Meier MF and 7 others (2007) Glaciers dominate eustatic sea-level rise in the 21st century. Science, 317(5841), 1064-1067 (doi: 10.1126/science.1143906)

Moholdt G, Nuth C, Hagen JO and Kohler J (2010) Recent elevation changes of Svalbard glaciers derived from ICESat laser altimetry. Remote Sens. Environ., 114(11), 2756-2767 (doi: 10.1016/ j.rse.2010.06.008)

Moiwo JP, Yang Y, Tao F, Lu W and Han S (2011) Water storage change in the Himalayas from the Gravity Recovery and Climate Experiment (GRACE) and an empirical climate model. Water Resour. Res., 47(W7), W07521 (doi: 10.1029/2010WR010157)

Nuth C and Kääb A (2011) Co-registration and bias corrections of satellite elevation data sets for quantifying glacier thickness change. Cryosphere, 5(1), 271-290 (doi: 10.5194/tc-5-2712011)

Pavlis NK, Holmes SA, Kenyon SC and Factor JK (2012) The development and evaluation of the Earth Gravitational Model 2008 (EGM2008). J. Geophys. Res - Solid Earth, 117(B4), B04406 (doi: 10.1029/2011JB008916)

Phan VH, Lindenbergh R and Menenti M (2012) ICESat derived elevation changes of Tibetan lakes between 2003 and 2009. Int. J. Appl. Earth Obs. Geoinform., 17, 12-22 (doi: 10.1016/ j.jag.2011.09.015) 
Sauber J, Molnia B, Carabajal C, Luthcke S and Muskett R (2005) Ice elevations and surface change on the Malaspina Glacier, Alaska. Geophys. Res. Lett., 32(23), L23S01 (doi: 10.1029/ 2005GL023943)

Schutz BE, Zwally HJ, Shuman CA, Hancock D and DiMarzio JP (2005) Overview of the ICESat Mission. Geophys. Res. Lett., 32(21), L21S01 (doi: 10.1029/2005GL024009)

Shi Y (1990) Glacier recession and lake shrinkage indicating the climatic warming and drying trend in central Asia. Acta Geogr. Sin., 45(1), 1-13 [in Chinese with English summary]

Song C, Huang B and Ke L (2013) Modeling and analysis of lake water storage changes on the Tibetan Plateau using multimission satellite data. Remote Sens. Environ., 135, 25-35 (doi: 10.1016/j.rse.2013.03.013)

Sørensen LS and 7 others (2011) Mass balance of the Greenland ice sheet (2003-2008) from ICESat data - the impact of interpolation, sampling and firn density. Cryosphere, 5(1), 173-186 (doi: 10.5194/tc-5-173-2011)

Wang X and 9 others (2013) Water-level changes in China's large lakes determined from ICESat/GLAS data. Remote Sens. Environ., 132, 131-144 (doi: 10.1016/j.rse.2013.01.005)

Williams RS Jr, Hall DK and Chien JYL (1997) Comparison of satellite-derived with ground-based measurements of the fluctuations of the margins of Vatnajökull, Iceland, 1973-92. Ann. Glaciol., 24, 72-80

Wu Y and Zhu L (2008) The response of lake-glacier variations to climate change in Nam Co Catchment, central Tibetan Plateau, during 1970-2000. J. Geogr. Sci., 18(2), 177-189 (doi: 10.1007/ s11442-008-0177-3)

Yi, D, Sun X and Zwally HJ (2003) A study of the GLAS echo waveform using ground test data. Geophys. Res. Abstr., 5, 13690
Yi D, Zwally HJ and Robbins JW (2011) ICESat observations of seasonal and interannual variations of sea-ice freeboard and estimated thickness in the Weddell Sea, Antarctica (2003-2009). Ann. Glaciol., 52(57), 43-51 (doi: 10.3189/ 172756411795931480)

Zhang G, Xie H, Duan S, Tian M and Yi D (2011a) Water level variation of Lake Qinghai from satellite and in situ measurements under climate change. J. Appl. Remote Sens., 5(1), 053532 (doi: 10.1117/1.3601363)

Zhang G, Xie H, Kang S, Yi D and Ackley SF (2011b) Monitoring lake level changes on the Tibetan Plateau using ICESat altimetry data (2003-2009). Remote Sens. Environ., 115(7), 1733-1742 (doi: 10.1016/j.rse.2011.03.005)

Zhang G, Xie H, Yao T and Kang S (2013) Water balance estimates of ten greatest lakes in China using ICESat and Landsat data. Chinese Sci. Bull., 58(31), 3815-3829 (doi: 10.1007/s11434013-5818-y)

Zhang Y, Liu C, Tang Y and Yang Y (2007) Trends in pan evaporation and reference and actual evapotranspiration across the Tibetan Plateau. J. Geophys. Res., 112(D12), D12110 (doi: 10.1029/ 2006JD008161)

Zhou S, Kang S, Gao T and Zhang G (2010) Response of Zhadang glacier runoff in Nam Co Basin, Tibet, to changes in air temperature and precipitation form. Chinese Sci. Bull., 55(20), 2103-2110 (doi: 10.1007/s11434-010-3290-5)

Zhou S, Kang S, Chen F and Joswiak DR (2013) Water balance observations reveal significant subsurface water seepage from Lake Nam Co, south-central Tibetan Plateau. J. Hydrol., 491, 89-99 (doi: 10.1016/j.jhydrol.2013.03.030)

Zwally HJ and 15 others (2002) ICESat's laser measurements of polar ice, atmosphere, ocean and land. J. Geodyn., 34(3-4), 405-445 (doi: 10.1016/S0264-3707(02)00042-X) 